\title{
Physiological and Ecological Characteristics of Sugarcane Field Weeds in the Ryukyu Islands
}

\author{
10. Competition between Sugarcane and Rottboellia exaltata L.f. \\ at Earlier Stages of Cane Growth
}

\author{
Yukio Ishimine*, Seiichi Murayama* and Sigeo Matsumoto** \\ * Faculty of Agriculture, Ryukyu University, Okinawa 903-01 \\ ** Faculty of Agriculture, Kyushu University, Fukuoka 812
}

\section{Introduction}

Research to determine the nature, extent or amount of crop-weed competition has been reported by several investigators ${ }^{6,711,14)}$. TA. KAYANAGI and IWATA ${ }^{13)}$, working on annual weed species Digitaria ciliaris KOEL. and upland rice, found that the weed competes severaly with the crop, especially in the production of dry matter, exerting a considerable influence on crop growth. ARAI ${ }^{1)}$ emphasized that in order to illuminate the mechanism by which a crop competes with a weed, the autoecological characteristics of the weed should be evaluated for the various factors involved in the competition. According to NOGUCHI et al. ${ }^{9)}$, a knowledge of competition between the crop and the weed, particularly for light, is essential to establishing an effective system of controlling the weed. BLACKMAN and TEMPLEMAN ${ }^{2)}$ reported soil nutrients, light and soil water to be factors involved in the competition, while RADEMACHER ${ }^{12)}$ has shown that competition among plants is closely related to the severity of shade they are subjected to.

Rottboellia exaltata L. f. a grass plant, is larger and has a higher cover than any other annuals that infest sugarcane fields. This weed species occurs two times a year, March and September, and bears fruit in May and November. Sugarcane is planted twice a year, between March and April (spring planting) and between October and September (summer planting). Thus, the planting of the crop coincides with the occurrence of the weed with the result that the growth of the crop is affected by competition from the weed which grows at a faster rate.The growth response of the weed to soil nutrients, shading and soil water has been reviewed in previous reports ${ }^{3 \sim 5)}$. In the present study, the pattern of interspecific competition for light that arises when the crop and weed are grown together was investigated.

\section{Materials and Methods}

The experiment was conducted from March 25 through July, 1987 at the Experimental Farm of the Faculty of Agriculture, Ryukyu University, located at Senbaru, Nishihara-cho, Okinawa Prefecture. The soil type in the field was a coral limestone. The Rottboellia seed was collected in November 1986 at the Experimental Farm. Two-node cuttings were harvested in the field from the top of the sugarcane (Okinawa Prefecture recommended variety Nco 310). A randomized block design was used with three replications. The plots, each 4 square meters, con- 
sisted of one pure plot where the crop or weed was grown alone and four mixed plots where the crop and weed were grown together. The mixed plots will hereafter be referred to as plot A-1, plot A-2, plot A-3, plot A-4, respectively. Plot A-1 was left unweeded for a period of 30 days, plot A-2 for a period of 60 days, plot A-3 for a period of 90 days, and plot A-4 for a period of 120 days after planting or seeding. The sugarcane cuttings were planted at a density of 12 cuttings in hills $110 \mathrm{~cm}$ apart and in rows $20 \mathrm{~cm}$ apart. The Rottboellia seed was sown at a density of 5- 6 seeds at $10 \mathrm{~cm}$ spacings and 2 weeks after emergence the plants were hand-thinned to a uniform stand of 1 plant per space. Planting or seeding date was March 25, 1987. The individual plots were fertilized with a compound fertilizer $(\mathrm{N}: \mathrm{P}: \mathrm{K}=3.6: 2.0: 2.8)$ first on March 25 and then on May 25, at the rate of $3.7 \mathrm{~kg} / \mathrm{a}$. Sampling was done on four different dates: April 24, March 23, June 21 and July 21, namely, 30, 60, 90, 120 days, after planting or seeding.

The growth of the crop was recorded on each sampling date for plant length, plant height, number of tillers, leaf area $\left(\mathrm{dm}^{2} / \mathrm{m}^{2}\right)$, leaf dry weight $\left(\mathrm{g} / \mathrm{m}^{2}\right)$, top dry weight $\left(\mathrm{g} / \mathrm{m}^{2}\right)$, diameter of main stalk, main stalk dry weight, and tillering stalk dry weight. The growth of the weed was recorded for plant height and top dry weight at various weedings.

For the crop the soil-surface relative light intensity in the community was measured in the middle of the rows and in the middle of the hills on the various sampling dates, with the aid of two illuminometers (Toshiba Sp Model 15), during the hours that the sun was passing the meridian line.

\section{Results and Discussion}

NOGUCHI and NAKAYAMA ${ }^{10)}$ noted that in order to evaluate the severity of damage from weed competition, variation in the growth of plant height or main stem length should be investigated between the crop and the weed and whether any competition for light exists between them should be determined. In the present study, the top growth response of the crop and weed to light at various weedings was examined.

The postplanting relative light intensity data for the pure plot of the crop is illustrated in Fig. 1. The relative light intensity started to decrease slowly in the hill and quickly in the row after the first 30 days of planting, the intensity value 60 days after planting being $38 \%$ in the row and $89 \%$ in the hill. At the last sampling, 120 days after planting, the figure was $2 \%$ in the row and $9 \%$ in the hill.

In a previous report ${ }^{4)}$, the growth of the weed was suppressed more as shading was increased and was most severe at $6 \%$ relative light intensity. From this result and the result described above it may be suggested that the growth of the weed will be influenced more severely under lower relative light intensities.

The growth data for the plant height and plant length of the crop and plant height of the weed are illustrated in Fig. 2. Plant height was measured at the highest point of the

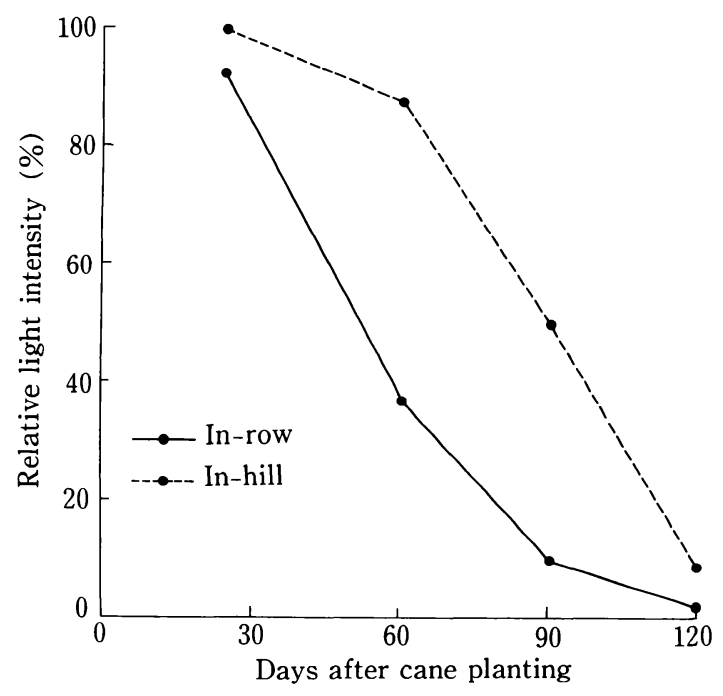

Fig.1. Changes in relative light intensity within community, pure plot. 
stand and plant length was taken at the longest point of the plant ${ }^{13)}$.

In the pure plot, growth of the plant height of the weed 30 days after seeding was small, compared with the plant height and plant length of the crop but a quick increase took place at 90 days after seeding, the value being $140 \mathrm{~cm}$, while the plant height of the crop at this stage of the growing period was $138 \mathrm{~cm}$. At the last sampling, 120 days after planting, the plant height and length of the crop reached $228 \mathrm{~cm}$ and $245 \mathrm{~cm}$, respectively, compared with $233 \mathrm{~cm}$ of the plant height of the weed.

In plot A-1 which was left unweeded for 30 days, both the crop and the weed showed essentially the same degree of growth as the pure plot results. At 30 days after planting the crop grew to $52 \mathrm{~cm}$ in plant height and $56 \mathrm{~cm}$ in plant length, compared with the pure plant results of $54 \mathrm{~cm}$ and $59 \mathrm{~cm}$. At 30 days after seeding the plant height of the weed grew to $32 \mathrm{~cm}$, while the pure plant result was $34 \mathrm{~cm}$. At the last sampling, 120 days after planting, the crop grew to $222 \mathrm{~cm}$ in plant height and $241 \mathrm{~cm}$ in plant length, compared with the pure plot results of $228 \mathrm{~cm}$ and $245 \mathrm{~cm}$.

Since the weed has little effect on the growth of the crop during the first 30 days of seeding, it is desirable that the weed be removed between 30 and 60 days after emergence or before it starts exerting a competitive effect on the crop.

In plot A-2 which was left unweeded for 60 days, the crop grew to $80 \mathrm{~cm}$ in plant height and $91 \mathrm{~cm}$ in plant length 60 days after planting, compared with the pure plot results of $83 \mathrm{~cm}$ and $95 \mathrm{~cm}$. The growth of the weed 60 days after seeding showed no marked difference from the pure plot result. The growth of
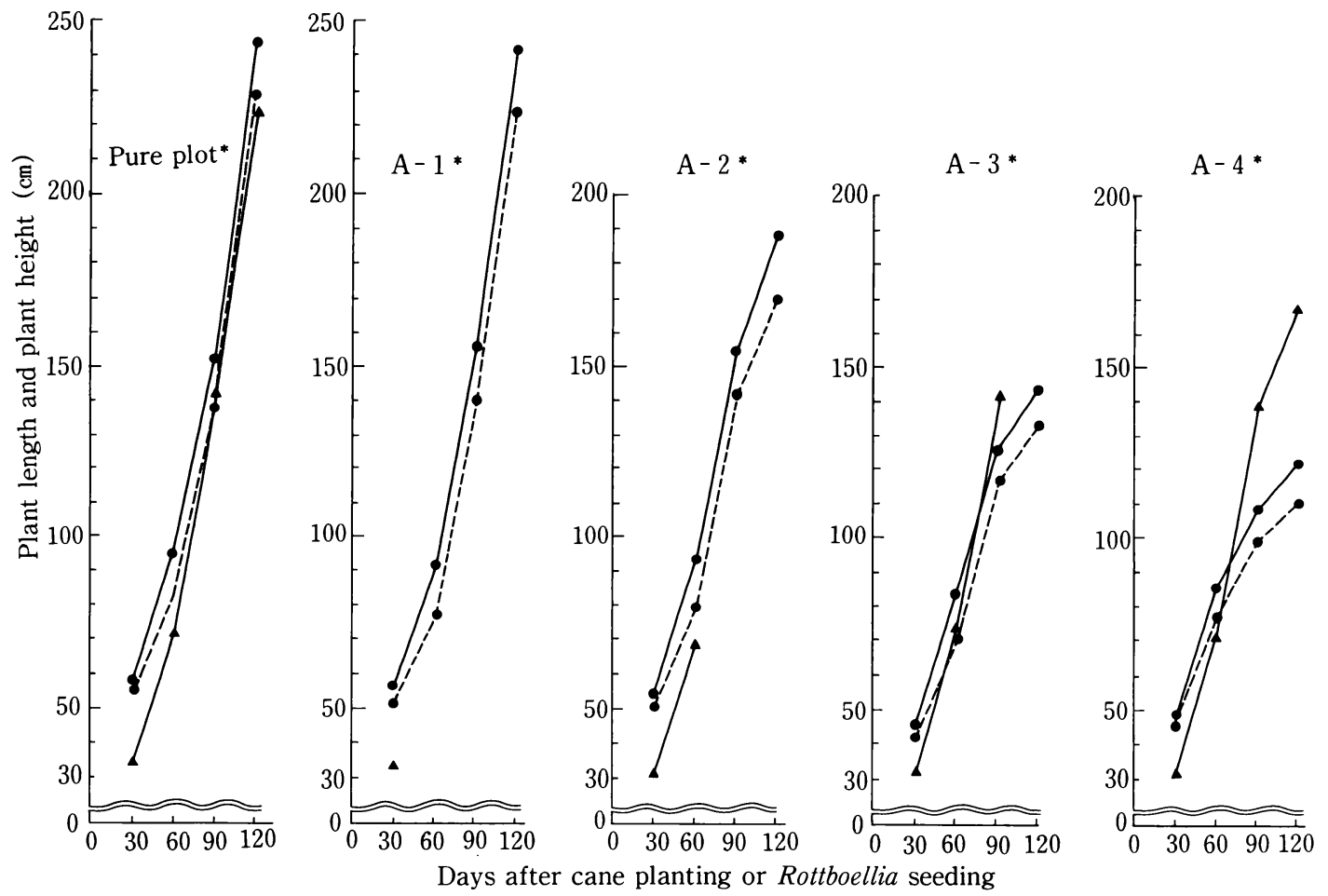

Fig.2. Changes in plant length and plant height of cane and changes in plant height of Rottboellia exaltata L. f. .

$\longrightarrow$ plant length (cane) --- plant height (cane) $\longrightarrow$ - plant height $($ Rottboellia $)$
$* \quad$ See Table 1. 
the crop 120 days after planting, however, was $170 \mathrm{~cm}$ in plant height and $188 \mathrm{~cm}$ in plant length, while the pure plot results were $228 \mathrm{~cm}$ and $245 \mathrm{~cm}$, suggesting that some effect of the weed still remained after it had been removed and that the longer weeding is delayed, the more the crop will be affected.

In plot A-3 which was left unweeded for 90 days, the growth of the crop 90 days after planting was $116 \mathrm{~cm}$ in plant height and $127 \mathrm{~cm}$ in plant length, while the pure plot results were $138 \mathrm{~cm}$ and $151 \mathrm{~cm}$. In contrast, the plant height of the weed 90 days after seeding was $140 \mathrm{~cm}$, which was essentially comparable to the pure plot result. The growth of the crop 120 days after planting was $132 \mathrm{~cm}$ in plant height and $143 \mathrm{~cm}$ in lenght, compared with the pure plot results of $228 \mathrm{~cm}$ and $245 \mathrm{~cm}$, which clearly indicates the effect of delayed weeding.

In plot A-4 which was left unweeded for 120 days, the growth of the crop 120 days after planting was $105 \mathrm{~cm}$ in plant height and $121 \mathrm{~cm}$ in plant length, approximately one half of the pure plant results of $228 \mathrm{~cm}$ and $245 \mathrm{~cm}$. In contrast, the plant height of the weed 120 days after seeding was $187 \mathrm{~cm}$, while the value for the pure plot was $222 \mathrm{~cm}$, indicating that delayed weeding increased the weed's competitive advantage over the crop.

Variation in leaf area, leaf dry weight and specific leaf area is illustrated in Table 1. The leaf area includes only the green parts of leaf foliage. In plot A-1, the crop leaf area (LA) and leaf dry weight (LDW) 120 days after planting were essentially comparable to the pure plot results but were reduced to $1 / 5$ and $1 / 20$ in plot $A-2$, to $1 / 15$ and $1 / 8$ in plot A-3, to $1 / 30$ and $1 / 14$ in plot $A-4$, respectively, of the pure plot results. The specific leaf area showed little difference between plot A-1 and the pure plot but was reduced to one half of the pure plot results in plots A-2,A-3 and A-4.

As will be seen from Table 2, the crop growth was largest in all characters in the pure and A-1 plots and a quick decrease took place in plot A-2, particularly in top dry weight, tillering stalk number and tiller num-

Table 1. Comparison of sugarcane leaf area (LA), leaf dry weight (LDW) and specific leaf area (SLA).

\begin{tabular}{cccc}
\hline \hline Number of days left unweeded after planting & $\mathrm{LA}\left(\mathrm{dm}^{2} / \mathrm{m}^{2}\right)$ & $\mathrm{LDW}\left(\mathrm{g} / \mathrm{m}^{2}\right)$ & $\mathrm{SLA}\left(\mathrm{dm}^{2} / \mathrm{g}\right)$ \\
\hline 0 (Pure plot) & $293.65 \mathrm{a}$ & $296.32 \mathrm{a}$ & $0.99 \mathrm{a}$ \\
30 (A-1) & $295.40 \mathrm{a}$ & $296.05 \mathrm{a}$ & $0.99 \mathrm{a}$ \\
$60(\mathrm{~A}-2)$ & $61.02 \mathrm{~b}$ & $141.90 \mathrm{~b}$ & $0.43 \mathrm{c}$ \\
$90(\mathrm{~A}-3)$ & $20.31 \mathrm{c}$ & $36.51 \mathrm{c}$ & $0.55 \mathrm{~b}$ \\
$120(\mathrm{~A}-4)$ & $10.54 \mathrm{c}$ & $22.90 \mathrm{c}$ & $0.46 \mathrm{c}$ \\
\hline
\end{tabular}

* Means not followed by the same letter are different at the $5 \%$ level of significance, as determined by Duncan's multiple range test.

Table 2 . Relation between weeging time and growth of sugarcane.

\begin{tabular}{|c|c|c|c|c|c|c|}
\hline $\begin{array}{l}\text { Number of days } \\
\text { left unweeded after } \\
\text { planting }\end{array}$ & $\begin{array}{l}\text { Main stalk } \\
\text { length } \\
(\mathrm{cm})\end{array}$ & $\begin{array}{c}\text { Main stalk } \\
\text { diameter } \\
(\mathrm{cm})\end{array}$ & $\begin{array}{l}\text { Main stalk } \\
\text { dry weight } \\
\qquad\left(\mathrm{g} / \mathrm{m}^{2}\right)\end{array}$ & $\begin{array}{l}\text { Number of } \\
\text { tillers } \\
\text { (/plant) }\end{array}$ & $\begin{array}{l}\text { Tiller dry } \\
\text { weight } \\
\left(\mathrm{g} / \mathrm{m}^{2}\right)\end{array}$ & $\begin{array}{l}\text { Top dry } \\
\text { weight } \\
\left(\mathrm{g} / \mathrm{m}^{2}\right)\end{array}$ \\
\hline 0 (Pure plot) & $241.6(100.0) \mathrm{a}$ & $5.20(100.0) \mathrm{a}$ & $374.1(100.0) \mathrm{a}$ & $6.4(100.0) \mathrm{a}$ & $395.1(100.0) \mathrm{a}$ & $1234.6(100.0) \mathrm{a}$ \\
\hline $30(A-1)$ & $240.3(99.4) \mathrm{a}$ & $4.60(88.4) \mathrm{a}$ & $370.9(99.1) \mathrm{a}$ & $6.5(101.5) \mathrm{a}$ & $390.8(98.9) \mathrm{a}$ & $1291.2(104.5) \mathrm{a}$ \\
\hline $60(A-2)$ & $188.1(77.8) b$ & $2.26(43.4) \mathrm{b}$ & $116.4(31.1) \mathrm{b}$ & $2.7(42.1) b$ & $119.4(30.2) \mathrm{b}$ & $429.4(34.9) \mathrm{b}$ \\
\hline $90(A-3)$ & $141.2(58.4) \mathrm{c}$ & $0.93(17.8) c$ & $82.5(22.0) \mathrm{c}$ & $1.4(21.8) \mathrm{c}$ & $92.5(23.4) c$ & $244.6(19.8) c$ \\
\hline $120(A-4)$ & $120.0(49.6) \mathrm{c}$ & $0.80(15.3) c$ & $39.4(10.5) \mathrm{d}$ & $0.3(4.6) \mathrm{d}$ & $11.3(2.8) \mathrm{d}$ & $83.5(6.7) \mathrm{d}$ \\
\hline
\end{tabular}

* Means not followed by the same letter are different at the $5 \%$ level of significance, as determined by Duncan's multiple range test.

( ) : Index, \%. 
ber. In plot A-4, the top dry weight was reduced to about $1 / 15$, the tillering stalk weight to about $1 / 35$, the tiller number to about $1 / 20$, respectively, of the pure plot. The main stalk length, main stalk diameter and main stalk weight were reduced to about $1 / 2$, $1 / 6,1 / 9$, respectively.

The effect of the various weeding times is less distinct on the main stalk length but is very remarkably reflected in the main stalk weight, tiller number and tillering stalk weight that are critical factors in determining sugarcane yield ; in plot A-2 the main stalk weight was reduced to $1 / 3$ and tillering stalk weight was reduced to $1 / 3$ of the pure plot results. All the characters of the crop were largest in the pure plot and in plot A-1 which was left unweeded for 30 days and started decreasing at a fast rate in plot A-2 which was left unweeded for 60 days. A possible explanation for such rapid reduction with prolonged weeding is that, on one hand, the canopy shading by the weed, that increased at later weedings, had an effect on crop growth and on the other, competition for soil nutrient and soil water occurred between the crop and weed throughout the growing period. It may, therefore, be suggested that the weed should be removed between 30 and 60 days after the crop is planted in order to minimize yield reduction in the crop.
The interaction between the crop and the weed as evaluated by the percentage suppression is illustrated in Table 3 . The percentage surpression was determined in accordance with the procedure proposed by KATO and SUNOHARA ${ }^{8)}$.

The growth of the crop was increasingly suppressed by the weed competition with prolongation of the weeding period and at the last sampling, 120 days after planting, suppression by the weed reached a maximum, $82 \%$, in plot A-4, indicating that the effect of the weed was severest in this treatment, while weed suppression by the crop 120 days after seeding was $19.5 \%$.

Since the competitive efficiency of the weed increases in the middle of the crop growing period, the proper time for control of the weed appears to lie within between 30 and 60 days after emergence.

\section{Summary}

In this investigation conducted under field conditions, Rottboellia exaltata L. f., a grass plant and the largest of the annual weed species occurring in sugarcane fields was chosen to evaluate its competitive effects on sugarcane. The results are summarized as follows:

1. The soil-surface relative light intensity in the sugarcane pure plot started decreasing

Table 3. Growth suppression between sugarcane and Rottboellia exaltata L. f..

\begin{tabular}{|c|c|c|c|c|c|c|c|c|}
\hline \multirow{3}{*}{$\begin{array}{l}\text { Number of days } \\
\text { left unweeded } \\
\text { after planting }\end{array}$} & \multicolumn{8}{|c|}{ Days after cane planting or Rottboellia seeding } \\
\hline & \multicolumn{4}{|c|}{$\begin{array}{l}\text { a : Cane growth suppression } \\
\text { by Rottboellia }\end{array}$} & \multicolumn{4}{|c|}{$\begin{array}{c}\text { b : Rottboellia growth suppression } \\
\text { by cane }\end{array}$} \\
\hline & 30 & 60 & 90 & 120 & 30 & 60 & 90 & 120 \\
\hline 0 (Pure plot) & - & - & - & - & - & - & - & - \\
\hline $30(A-1)$ & $2.4 \%$ & 2.9 & 4.7 & 8.2 & 1.7 & - & - & - \\
\hline $60(A-2)$ & 2.6 & 29.4 & 31.7 & 34.1 & 1.7 & 5.8 & - & - \\
\hline $90(A-3)$ & 2.9 & 35.0 & 52.4 & 67.7 & 1.7 & 5.8 & 10.4 & - \\
\hline $120(\mathrm{~A}-4)$ & 2.8 & 33.9 & 63.6 & 82.0 & 1.7 & 5.8 & 10.4 & 19.5 \\
\hline
\end{tabular}

\footnotetext{
a : $\frac{\text { Cane dry weight, pure plot }- \text { Cane dry weight, mixed plot }}{\text { Cane dry weight, pure plot }} \times 100(\%)$

b : $\frac{\text { Rottboellia dry weight, pure plot }- \text { Rottboellia dry weight, mixed plot }}{\text { Rottboellia dry weight, pure plot }} \times 100$ (\%)
} 
quickly in the row and slowly in the hill after the first 30 days of planting. The value at the last sampling, 120 days after planting, was $2 \%$ in the row and $9 \%$ in the hill.

2. The pure-plot plant height value for the weed 30 days after seeding was consistently smaller than either the plant length or the plant height of the crop, while it was larger than the plant length of the crop 90 days after seeding.

3. The weed showed no growth difference from the crop between plot A-1 and the pure plot during the first 30 days of seeding. A similar trend was observed with plot A-2 during the first 90 days of seeding. The mixed-plot growth of the crop 120 days after planting was remarkably small, compared with the pure plot result. In plot A-3 growth 90 days after planting was smaller than the pure plot result, while growth of the weed was essentially comparable to the pure plot. The mixed-plot growth of the crop 120 days after planting was small, compared with the pure plot. In plot A-4 growth 120 days after planting was reduced to about one half of the pure plot. The mixed-plot growth of the weed 120 days after seeding was considerably smaller than the pure plot.

4. In the mixed-plots the leaf area (LA), leaf dry weight (LDW) and specific leaf area (SLA) decreased quickly as the period of weeding was prolonged.

5. In the mixed-plots the main stalk length, main stalk diameter, main stalk weight, tiller number, tillering stalk weight and top dry weight similarly decreased quickly as the period of weeding was prolonged.

6. In plot A-4 both the crop and the weed were suppressed with the lapse of the growing period. At 120 days after planting the crop was suppressed $82 \%$ and the weed was suppressed $19.5 \%$.

7. The competitive effects of the weed became distinct after the first 30 days of seeding. The main stalk weight, tiller number and tillering stalk weight, which are critical factors in determining sugarcane yield, started decreasing quickly at 60 days after planting. The values at the last sampling, 120 days after planting, were about $1 / 9,1 / 20$ and $1 / 35$, respectively, of the pure plot results. The weed should be removed between 30 and 60 days after emergence in order to minimize yield reductions of the crop from competition with the weed.

\section{References}

1) ARAI, M. (1965) : Weed Res., Japan 4, 1-10.(in Japanese).

2) Blackman, G. E and W. G. Templeman (1938) : Jour. Agr. Sci. 28, 247-271.

3) ISHIMINE, Y., S. MURAYAMA and S. MA. TSUMOTO (1988) : Weed Res., Japan. 33,14-22.

4) ISHimine, Y., S. MURAYAma and S. MATSUMOTO (1988) : Weed Res., Japan (submit).

5) ISHIMine, Y., S. MURAYAMA and M. NA. KAMA (1988) : Sci. Bull. Coll. Agr. Univ. Ryukyus (submit).

6) ISHimine, Y., S. MURAYAma and S. MATSUMOTO (1988) : Weed Res., Japan (submit).

7) JORGE, N. H. and D. W. STANIFORTH (1961) : Agron. J. 53, 1-5.

8) KaTO, T and W. SunOHARA (1966) : Weed Res., Japan 5, 23-33 (in Japanese).

9) NOGUCHI, K., K. NAKAYAMA and M. TA. KABAYASHI (1977) : Japan. Jour. Crop Sci. 46, 504-509 (in Japanese with English summary).

10) NogUCHI, K., K. NAKAYAMA (1982) : Weed Res., Japan 27, 198-203 (in Japanese with English summary).

11) Oliver, R. E., R. E. FRANS and R. E. TAL. BERT (1976) : Weed Res., 24, 482-488.

12) RADEMACHER, B. (1939) : Pflanzenbau 15, 241-265.

13) TAKAyAnagi, S. and I. IWATA (1978) : Weed Res., Japan 23 (2), 11-18 (in Japanese with English summary).

14) Vesecky, J. F., K. C. Feltber and R. L. VANDERLIP (1973) : Weed Res., 21, 28-32.

(Received December 25, 1987) 
琉球列島のサトウキビ畑における雑草の生理・生態

第10報＼cjkstart生育初期におけるサトウキビとツノアイアシの競合

石嶺行男・村山盛一 琉球大学農学部

松本重男 九州大学農学部

摘

要

サトウキビ畑の一年生草のうちサトウキビの生育または収量に有害な影響を及ほすと推定されるイネ科のッ ノアイアシをサトウキビと混植し, 両草種の競合によって相互の生育に現れる反応の程度を調べるととに, 両草種をそれぞれ単植した場合すなわち競合のない条件下で栽培した時の結果を比較検討することにより，ツ ノアイアシの特性を主として光競合の観点から明らかにすることを試みた。

1.サトウキビの単植区における地表面相対照度は, 生育期間の経過とともに直線的に減少し, 植付後 120 日 に株間で $2 \%$, 畦間で $9 \%$ に低下した。今回の実験範囲には植付後 120 日以降すなわちサトウキビの初期生育後 における生育および相対照度の推移は含まれていないが，この結果から推測するとサトウキビの群落内でッノ アイアシはサトウキビの生育に伴って受光量が減少し，もしくは遮光が増大すれば，その影響を受けて生育を 阻害されるものと思われる。

2. 単植区間では, ツノアイアシの生育は生育期間の初めにサトウキビに劣り，中ごろには急激に伸長して サトウキビに勝ったが，生育期間の終りの播種後120後には生育は再びサトウキビに劣った。

3. 混植後30日間除草しなかった区では, 除草時におけるツノアイアシの影響はほとんど認められず，サト ウキビはそれ以降も単植区とほほ等しい生育推移を示した。

4. 混植後60日間除草しなかった区でも，上述同様に除草時におけるッノアイアシの影響はほとんど認めら れなかったが，生育期間の終りにサトウキビの生育に変化が現れ単植区に比べて著しく劣る結果を示した。こ のように除草放任期間が30日の場合と60日の場合でサトウキビの生育に差が生じたのは, 後者で除草後もッ) アイアシの影響が消滅せず残存したことをうかがわせた。

5. 混植後 90 日間除草しなかった区では，サトウキビの生育は単植区に比へ除草の時点ですでにツノアイア シに著しく劣り，それ以降も上述同様ツノアイアシの残存影響を反映して生育が低下し，生育期間の終りには ツノアイアシとの間にさらに顕著な差が生じている。

6. 混植後120日間除草しなかった区でも, サトウキビの生育は単植区に比べて, ツノアイアシに著しく劣り, 除草時期の遅延によってッノアイアシの影響が顕著に現れてくることがうかがわれた。

7. サトウキビの収量決定に大きく関与する主茎重，分げつ数および分げつ茎重は除草時期が生育期間の初 めを過ぎると急激に減少しており除草時期の遅延に伴って減収が生じる可能性があることが推察された。しか し，この結果が単に光競合によるものかどうかは不明で，これに加えて両草種間における土壤養分や水分の奪 い合いが関与要因として考えられる。

8. 上述の実験結果を整理すると,ッノアイアシの除草時期としてはサトウキビの生育に影響が生じない出 芽後30日以内が除草効果および省力の点からみて適切であると判断される。 